This is the final draft of an article published in Kantian Review 16 (3): 325-349. Please cite the published version, available at

https://www.degruyter.com/view/j/kant.2013.104.issue-2/kant-2013-0014/kant-2013-0014.xml, which differs in the standard ways (formatting, pagination, small grammatical corrections, etc.) from the draft.

Indessen kennen wir denn doch das System des H. Hume aus seinen Versuchen; und, ob der Uebersetzung derselben gleich, von einem berühmten deutschen Philosophen, Anmerkungen und Zusätze beygefügt worden sind: so scheint doch $H$. Reid der Quelle des Uebelswenn ja Uebel bey der Sache ist-näher gekommen zu seyn, als irgend ein anderer Gegener des H. Hume,-wenn ich die einzelen Stellen, wo H. Kant (in der Critik der reinen Vernunft) ihn bestreitet ausnehme.

Translator's Preface, Untersuchungen über den Menschlichen Geist, 1782.

\title{
CAUSAl POWERS, HuME's EARLY GERMAN CRITICS, AND KaNT’S RESPONSE TO HUME
}

\author{
(forthcoming in Kant-Studien) \\ Brian A. Chance \\ University of Tennessee
}

The anonymous German translator of Reid's Inquiry into the Human Mind deserves a special place in the history of Kant studies, although for reasons neither he nor his readers could have anticipated. He was the first to suggest in print that much of Kant's Critique of Pure Reason is an attempt to refute the philosophical views of David Hume. Those who regard refuting Humean skepticism as central to Kant's critical project are thus following in the footsteps of a man whose name has been lost to history. And from the eighteenth-century until today, those interpreting the Critique in this light have regarded the refutation of Hume's account of causation as the focus of Kant's response to Hume. ${ }^{1}$

If recent interpretations of the Critique are correct, however, the publication of Reid's Inquiry in German does not mark the origin of one of the settled facts of Kant scholarship but of one of its most pervasive falsehoods. For some now claim Kant was not interested in refuting

$\dagger$ Citations from the Critique of Pure Reason are use the standard A/B format to refer to the pages of the first (A) and second (B) editions, while those from Kant's other works give the volume number and page number of the Academy Edition. Citations from Hume's Treatise and first Enquiry give the section and paragraph number of the passage followed by the page number of the Selby-Bigge and Nidditch editions (SBN). Other citations identify works by date of publication, sometimes including the date of a relevant earlier publication in square brackets [ ]. I have used the translations of Kant's works listed in the bibliography, in some cases with slight modifications. All other translations are my own.

${ }^{1}$ See, for example, Schultz 1785, 299; Pistorius 1786, 99; Tiedemann 1785; Reinhold 1791, 135-138; Schulze 1792, 131-180; Fischer 1860, 30-39; Vaihinger 1881, 3-11; and Kemp-Smith 1918, xxv-xxi, 61-64, 592-601. Sassen 2000 and Giovanni and Harris 2000 provide translations of the relevant parts of the eighteenth-century works. Not all of these authors believed that Kant's response was successful of course. Schultz suggested that Kant's views actually lead to Humean skepticism. Both Reinhold and Schulze charged Kant with begging the question against the Humean skeptic. Pistorius claimed that Kant's response to Hume actually resulted in a "Pyrrhonism without limit". And Tiedemann charged Kant with opening the way to both skepticism and idealism. 
Hume's account of causation in the Critique at all but rather in providing an alternative to it or to Hume's empiricist account of cognition more generally. Arguments for this revisionary view are varied, but the most explicit and detailed defense of it has been given by Eric Watkins in his book Kant and the Metaphysics of Causality. ${ }^{2}$ In it, Watkins advances three claims to justify his rejection of what, despite other differences, has remained a central tenant of our understanding of Kant's relationship to Hume for well over two hundred years. ${ }^{3}$ The first is that Kant's account of causation, when properly understood, is too different from Hume's for a refutation of Hume's account to be possible. The second is that Kant's explicit comments about Hume in the Critique suggest that Hume's account of causation was not important to him in its own right but only as an illustration of an approach to the critique of traditional metaphysics that Kant believed should be replaced by his own critical approach. The third is that neither Kant nor his readers would have thought Hume's account of causation stood in need of refutation, in part because it was not considered a serious threat to prevailing Wolffian and Leibnizian views. Watkins thus rejects the common assumption of an interpretation of Kant's relationship to Hume almost as old as the Critique itself on philosophical, textual, and historical grounds. In its place, he suggests that it is more accurate to characterize Kant's account of causation as an alternative to Hume's, that is, one that competes with it for adherents without being intended or able to refute it directly.

I am sympathetic to the reading of Kant's account of causation Watkins develops. But I am unconvinced by his attempt to show that this account is merely an alternative to Hume's. And much of this paper will be an attempt to articulate the reasons for my incredulity. In doing so, however, I do not defend the view that Kant's relationship to Hume is completely adversarial, as philosophers from Reinhold to Strawson have tended to claim. For while I do think that refuting Hume's account of causation is one of Kant's chief goals in the Critique, I also believe that Watkins is right to insist that Kant thought of Hume's account as a kind forerunner, albeit a less successful one, to his own critique of metaphysics. ${ }^{4}$ In what follows, I will argue (1) that the question of Kant's ability to refute Hume is independent of Watkins reading of Kant's account of

\footnotetext{
${ }^{2}$ Watkins 2005. See also Watkins 2004 and Hatfield 2001 and 2003.

${ }^{3}$ For Watkins' view, see Watkins 2005, 16-17, 362, and 381-389. For the purposes of this essay, I will ignore Watkins' discussion of Kant's pre-critical philosophy and its relation to his revised account of Kant's relationship to Hume. See especially Watkins 2005, 382. In isolation from the claims I will presently discuss, these considerations do not in my view provide compelling support for Watkins' characterization of Kant's relationship to Hume.

${ }^{4}$ In this respect, Watkins and I are both in agreement with a central strand of Kuehn 1983 and 1987b. Hatfield 2001 defends a similar view but, like Watkins, also maintains that refuting Hume is not one of Kant's aims in the Critique. My forthcoming Kantian Review article provides a detailed discussion of Kant's debt to Hume.
} 
causation, (2) that Kant's explicit comments about Hume in the Critique make clear that he conceives of his own account of causation as an attempt to refute Hume's, and (3) that none of Hume's early German critics provided responses to this account that would have satisfied Kant. Since Kant has the resources to refute Hume's account of causation, conceived of his own account as a refutation of Hume's, and could not have accepted the attempts to refute Hume by his contemporaries, I conclude that refuting Hume's account of causation is, in fact, one of Kant's central aims in the Critique and, in particular, in the Analogies of Experience.

\section{Hume and Causal Powers}

Consider first the claim that Kant cannot refute Hume. This is the strongest argument Watkins provides on behalf of his interpretation and the one he develops in the greatest detail. Since Watkins is concerned with whether Kant was trying to refute Hume, the argument that he was not because he could not makes tacit use of something like the principle of charity. If Kant's account of causation is too different from Hume's for a refutation of Hume's account to be possible and these differences are, moreover, apparent, then refuting Hume's account is likely not among Kant's goals. Such is the general structure of Watkins' argument. But Kant's account of causation does not limit him in the way Watkins believes it does. For one may grant his reading and still maintain that the strategy Kant is usually thought to employ against Hume is a viable one. In order to see why this is true, we first need to look at this reading in more detail.

Watkins' reading rests on his characterization of the different the models of causation Kant and Hume employ. Kant's account of causation in the Analogies of Experience is, as Watkins interprets it, an example of a causal powers model. Specifically, Watkins holds that Kant's account commits him to an ontology of phenomenal substances and causal powers, the latter of which are understood as grounds, that is, as unchanging and temporally indeterminate aspects of a substance's essential nature capable of producing temporally determinate changes of state in other substances. Given this basic ontology, causes are conceived as phenomenal substances, while effects are conceived as continuous changes in the state of one substance produced by the causal power of another substance. ${ }^{5}$ Hume's account of causation, in contrast, is an example of an event-event model. According to Watkins, the ontology underlying this model is one of events understood as discrete, temporally determinate states of affairs, and it is in terms

\footnotetext{
${ }^{5}$ Watkins 2005, 243-297.
} 
of events that the elements of Hume's account of causation, causes and effects, are defined. More specifically, a cause on Watkins' reading of Hume is a determinate state of affairs regularly followed by another determinate state, while an effect is a determinate state of affairs regularly proceeded by another determinate state. ${ }^{6}$

Because of their radically different conceptions of causes and effects, Kant and Hume also have radically different conceptions of the relationship that obtains between a cause and its effect. For Hume this relationship is, famously, one of the constant conjunction of two events (the cause and its effect), while for Kant it is a relationship between aspects of the essential nature of one substance and the continuous change of state of another substance. Because there is no overlap between their conceptions of causes, effects, or the relationship obtaining between them, Watkins concludes that Kant's account of causation cannot refute Hume's "since it is always open to Hume to reject the very starting point of Kant's argument (on the grounds that he does not share his most fundamental assumptions)". 7 From a dialectical point of view, that is, neither Kant nor Hume is in a position to question the other's views without begging the question against them. And this inability to refute Hume in principle is, Watkins believes, the strongest evidence that this is not what Kant is trying to do in the Critique. ${ }^{8}$

But even if Kant does employ a causal powers model of causation, this does not prevent his account from being a refutation of Hume's. In the first place, to suppose that it does assumes an implausibly narrow notion of refutation. ${ }^{9}$ The argument sketched above suggests that one philosopher can refute another's position on a topic only if both share the same basic ontological commitments relevant to the topic. Understood in this way, refutations would be limited to arguments that begin with these shared commitments and point out that certain of a philosopher's conclusions are invalid or that valid conclusions can be drawn from them that are inconsistent with that philosopher's official view. And indeed Watkins suggests at a number of points that this is what he understands a refutation to be. ${ }^{10}$ But while an argument pointing out logical

\footnotetext{
${ }^{6}$ Ibid., 232-235.

${ }^{7}$ Ibid., 385.

${ }^{8}$ Ibid., 384.

9 Allias 2007, 215-216, Allison 2008, 354-355, and Guyer 2008, 17-20 make similar objections. I am indebted to conversations with Guyer on this point.

${ }^{10}$ Thus, in his initial discussion of his view, Watkins states that that "lack of a share vocabulary makes it impossible for one either to find a refutation of Hume's position in Kant's explicit arguments or to translate Kant's arguments into Humean terms such that the presuppositions required for a refutation to be possible would be satisfied" (17) And in subsequent discussions, he states that Kant and Hume do not "share enough assumptions for a refutation to be possible" and that the "stark contrast" between their "fundamental ontologies" makes it impossible to translate
} 
fallacies or implications of premises contrary to the view they are intended to support certainly qualifies as a refutation, there is no reason to insist on the additional requirement that the argument also proceed from a set of shared ontological premises.

To be sure, one cannot assume an ontology inconsistent with the view one targets and evoke that ontology to show that the view is wrong. But this is not what Kant is doing on Watkins' reading. Kant's ontology of phenomenal substances and causal powers is not a premise of the Analogies of Experience but their conclusion. And the arguments in support of this ontology will still qualify as a refutation of Hume's account of causation if they are able to show that a premise crucial to Hume's articulation of his account is actually inconsistent with it. And this is precisely the strategy Kant is typically thought to employ against Hume in the Analogies of Experience (or some subset of them) when he argues that knowledge of objective change presupposes the existence phenomenal substances, the validity of the causal law, and mutual interaction. ${ }^{11}$ Hume's reliance on our ability to know when change is objective as opposed to merely subjective can be seen in the common clause of the Treatise's two definitions of "cause". For it is of no help to define a cause as "an object precedent and contiguous to another" unless we are able to determine the temporal order of objects, and this is just what it means for Kant to have knowledge of objective change (T 1.3.14.31; SBN 170). As Watkins reads Kant, the arguments of the Analogies still show that this ability is inconsistent with the account of causation Hume endorses. And as long as they do, there is no reason to deny them the status of a refutation.

Perhaps more importantly, one may question on purely internal grounds whether Hume is entitled to the ontology Watkins attributes to him. As we have seen, the core of this ontology is Hume's conception of events as discrete, instantaneous states of affairs. But Hume's defense of this conception relies on his account of the finite divisibility of time. And his arguments for this

the elements of Kant's account of causation so that they are "expressible in Humean terms" $(362,386)$. Moreover, Watkins' attempt to elaborate his own position by way of contrast with the traditional view suggests that Kant must begin with Hume's assumptions about the nature of cause and effect in order to refute him: “That is, Kant's strategy is not to use a set of explanatory terms and concepts he shares with Hume to show how Hume failed to see which implications they had (which would amount to a refutation of Hume's position), but rather to provide a different set of concepts and doctrines that are supposed to obviate the very framework that Hume's approach presupposes." (386)

${ }^{11}$ Whether the first and third analogies are also relevant to Kant's response and, if so, in what way is a matter of debate. 
account are notoriously bad. ${ }^{12}$ One such argument, indeed the only one Hume makes specifically for time, is the following:

'Tis a property inseparable from time, and which in a manner constitutes its essence, that each of its parts succeeds another, and that none of them, however contiguous, can ever be co-existent [...] 'Tis certain then, that time, as it exists, must be compos'd of indivisible moments. For if in time we could never arrive at an end of division, and if each moment, as it succeeds another, were not perfectly single and indivisible, there would be an infinite number of co-existent moments, or parts of time; which I believe will be allow'd to be an arrant contradiction. (T 1.2.2.4; SBN 31)

Hume's argument is thus a reductio ad absurdum that attempts to establish the finite divisibility of time by showing that infinite divisibility is inconsistent with the uncontroversial premise that moments in time cannot coexist.

As it stands, Hume's argument is woefully incomplete since he has not given us any reason to think that the infinite divisibility of time implies the existence of infinitely many coexistent moments of time. In the context of his larger argument, however, Hume has introduced two other premises that may appear to help him establish this conclusion. The first is that "whatever is capable of being divided in infinitum, must consist of an infinite number of parts" (T 1.2.1.2; SBN 26). And the second, which needs modification to apply to time, is that "the idea of an infinite number of parts is individually the same with that of an infinite extension" (T 1.2.2.2; SBN 30). But these premises only help if we make the further assumption that time is of finite duration since no contradiction arises from supposing that an infinite duration is composed if infinitely many successive moments. ${ }^{13}$ Given these additional assumptions, Hume's claim may be that a finite but infinitely divisible duration implies the coexistence of infinitely many moments of time because infinitely many durations would all need to overlap, as it were, in order to all be part of any finite duration. Put another way, Hume may be arguing that the "arrant contradiction" of an infinite number of coexisting times follows from the assumption of a finite but infinitely divisible duration because the sum of these durations would be infinite and therefore able to be contained in any finite duration only if they were also able to coexist.

\footnotetext{
${ }^{12}$ See, for example, Flew 1976, Fogelin 1988, and Frasca-Spade 1990. For a compelling defense of Hume against these criticisms of the finite divisibility of space (but not time), see Holden 2002.

${ }^{13}$ This assumption is also a reasonable one since Hume's parallel arguments in the case of space explicitly assume a finite extension (T 1.2.2.2-3; SBN 29-30).
} 
But even if this is a plausible reconstruction of Hume's argument in the above passage, the argument is still seriously flawed. For it is simply not the case that "the idea of an infinite number of parts is individually the same with that of an infinite extension" or, to put Hume's claim in terms relevant to the case of time, that the idea of an infinite number of durations is the same as that of an infinite duration. As has often been pointed out in the case of space, this claim rests on the faulty assumption that all the parts of a whole must be equal since it is only on this assumption that an infinite number of durations are equal to an infinite duration. But since we are free to suppose that a finite duration may be made up of infinitely many finite and successively smaller durations, we are not forced to conclude that any of these constituent durations would need to coexist in order for all of them to be part of the whole. ${ }^{14}$ And if Hume cannot show that time is only finitely divisible, it will difficult if not impossible to establish on the basis of other arguments in the Treatise that events and, in turn, the relations between causes and effects are instantaneous and not continuous (as Watkins believes Kant claims). As such, Hume is unable to object to at least this part of Kant's account. The weaknesses of Hume's account of time thus provides additional evidence that adopting a causal powers model of causation still allows Kant to refute Hume in much the same way he is traditionally thought to do so.

Finally, Watkins arguably bases his case on the wrong text. Kant's knowledge of Hume's account of causation was based almost exclusively on the first Enquiry, which was translated into German in $1755 .{ }^{15}$ But the passages Watkins draws on to establish Hume's endorsement of an event-event model of causation are drawn exclusively from the Treatise. And these passages are not among the scant portions of the Treatise available in German during the composition of the Critique. ${ }^{16}$ So the relevant question for Watkins' reading of Kant's relationship to Hume is whether Hume's views on causation in the Enquiry commit him to an event-event model of

\footnotetext{
14 Thus, for any given finite duration $n$, the sum of the infinite series $\frac{1}{2} n, \frac{1}{4} n, \frac{1}{8} n, \frac{1}{16} n \ldots$ will not be greater than $n$.

15 The translation appeared as volume two of Hume's Vermischte Schriften and included an extensive commentary by the editor J.G. Sulzer. Although he says quite clearly in the Preface that the translation "came to him from good hands", Sulzer is sometimes mistaken for the translator as well (Hume 1755, b3). I return to Sulzer's commentary in section three.

${ }^{16}$ It is generally agreed that Kant's English was too poor for him to have read Hume's works in the original, on which see Erdmdann 1888. But portions of the Treatise were available to Kant prior to its 1790 translation into German from three sources. The first is Hamann's translation of the conclusion of Book One, which appeared in the Königsbergische gelehrte und Politische Zeitung in 1771. The other two are the 1772 German translation of James Beattie's Essay on the Nature and Immutability of Truth and J.N. Tetens 1777 Philosophical Essays on Human Nature and Its Development, both of which quote liberally from the Treatise. For more details on these and other sources, see Gawlick and Kreimendahl 1987, 174-198 and Kuehn 1983, 177-186.
} 
causation. If they do not, Watkins' worries about unbridgeable differences between Hume's and Kant's models disappear.

Hume's views on causation in the Enquiry remain a subject of controversy. But I believe it is uncontroversial that these views do not commit him to an ontology of events understood as discrete, instantaneous states of affairs and, therefore, that he is not committed to an event-event model of causation. Hume's previous account of time is completely absent from the Enquiry, and there are no comments that suggest he regards causes and effects as reducible to events in the way Watkins suggests he does in the Treatise. ${ }^{17}$ On the contrary, Hume frequently talks about causal powers in the Enquiry, and he often suggests that he accepts their existence and merely denies our ability to acquire knowledge of them. He tells us that the "ultimate springs and principles" of the world "are totally shut up from human curiosity and enquiry" and that nature "has afforded us only the knowledge of a few superficial qualities of objects; while she conceals from us those powers and principles, on which the influence of these objects entirely depends" (E 4.13, 16; SBN 31, 32). ${ }^{18}$ Our judgments about causal relations do no rely on knowledge of these powers in Hume's view. But he does not dispute their existence. Thus, if we evaluate Kant's ability to refute Hume on the basis of the text Kant knew best, the conflict Watkins identifies does not arise.

\section{KANT ON HUME: METAPHYSICS AND THE DENIAL OF SYNTHETIC A PRIORI KNOWLEDGE}

Consider now Kant's explicit comments about Hume. Watkins believes they show Kant's interest in Hume's account of causation was limited to its ability to undermine the claims of speculative reason that were Kant's targets in the Critique. ${ }^{19}$ But while it is true that Kant often

\footnotetext{
${ }^{17}$ Hume describes causes and effects as events in one paragraph of the Enquiry, where he comments that "every effect is a distinct event form its cause" and that we cannot "determine any single event, or infer any cause or effect, without the assistance of observation and experience" (E 4.11; SBN 30). But since these comments are followed by his discussion of causal powers, including elasticity and gravity, the notion of event implicit in these passages must be consistent with the existence of causal powers and is thus substantially different from the notion Watkins believes is implicit in the Treatise.

${ }^{18}$ These passages are among those cited by those who believe Hume to be a causal realist. See Read and Richman 2008 for a number of influential papers on this topic, which has come to be known as the "New Hume Debate".

${ }^{19}$ See Watkins 2005, 375-9. Surprisingly, Watkins does not include Kant's discussion of the "remembrance of David Hume" in the Prolegomena in his discussion of Kant's comments about Hume, but his discussion the paragraph following that passage a 4:360-1 makes clear that Watkins regards this remembrance as a reference to the role Hume's account of causation played in Kant's development of the distinction between real and logical grounds in the 1760's. See Watkins 2005, 169.
} 
characterizes Hume's aims in a way similar to his own, he is also critical of Hume, not only for failing to undermine the claims of speculative reason, as Watkins acknowledges, but also for attempting to do so in a way that eliminates the possibility of synthetic a priori knowledge. ${ }^{20}$ And while the first of these criticisms is consistent with Watkins' claim that Kant was only interested in Hume's account of causation as a means to limit the claims of speculative reason, the second makes clear that Kant was also interested in Hume's account because of its implications for our knowledge of objects of experience and thus for the transcendental theory of experience he develops in the Aesthetic and Analytic of the Critique. ${ }^{21}$

Kant's most well-known statement of this second criticism is in the Prolegomena, where he writes that Hume's analysis of the origin of the concept of cause "implies that there is no metaphysics at all, and cannot be any" (4:258). ${ }^{22}$ But his most important statement is in the "Discipline of Reason", the first and longest part of the "Doctrine of Method" in the Critique. This portion of the Critique is not only virtually identical in both editions, but it is also here that Kant frames the arguments of the Transcendental Analytic and, in particular, the Second Analogy as a response to the denial of synthetic a priori knowledge he believes Hume's account of causation entails. In terms reminiscent of his initial discussion of synthetic judgments in the Introduction (A7/B11), Kant here describes this denial as the denial of the "augmentation of concepts out of themselves and the parthenogenesis, so to speak, of our understanding" (A765/B793). He then proceeds to contrast Hume's account with his own:

In the transcendental logic, on the contrary, we have seen that although of course we can never immediately go beyond the content of the concept which is given to us, nevertheless we can still cognize the law of the connection with other things completely $a$ priori, although in relation to a third thing, namely possible experience, but still a priori. Thus if wax that was previously firm melts, I can cognize a priori that something must have proceeded (e.g. the warmth of the sun) on which this has followed in accordance with a constant law, though without experience, to be sure, I could determinately cognize neither the cause from the effect nor the effect from the cause a priori and without instruction from experience. (A766/B795)

\footnotetext{
${ }^{20}$ Passages where Kant characterizes Hume's aims in this way include A760/B789, 4:360-1, and 5:13. Kuehn 1987, 49-55 and my forthcoming discuss these and other passages.

${ }^{21}$ For statements of this first criticism, see A760/B788 and A768/B796. Watkins 2005, 380 acknowledges in passing that Kant thought Hume's account of causation committed him to a denial of synthetic a priori knowledge. But he seems to believe that Kant regarded this denial merely as a defect of Hume's view and not as a challenge to his own. ${ }^{22}$ By "metaphysics" Kant here means his own critical metaphysics, that is, the account of synthetic a priori knowledge whose outline he sketches in the Prolegomena.
} 
In this passage, Kant distinguishes between two types of knowledge of causal relations. The first, our knowledge that the melting of the wax was proceeded by something that caused it to melt according to a rule, is a type of knowledge grounded a priori in the validity of the principle of the Second Analogy. The second, our knowledge that the sun melted the wax, is knowledge of a particular causal relation, and Kant insists that this latter type of knowledge is always $a$ posteriori.

But the fact that our knowledge of particular causal relations relies essentially on experience and is thus contingent does not imply that those causal relations themselves are contingent. For if it is an a priori truth that all alterations are governed by "the law of connection of cause and effect", there must be some causal law that governs the interaction of particular objects like the piece of wax and the sun (B232). We may thus distinguish between our knowledge that a particular alteration (like the melting of the wax) has a cause, and our knowledge of what this cause is. The former is a piece of a priori knowledge established by the Second Analogy, while the latter is a piece of a posteriori knowledge that can only be known through experience. And it is precisely this distinction that Kant highlights in the above passage when he contrasts our a priori knowledge "that something must have proceeded" the melting of the wax "on which it has followed in accordance with a constant law" with our a posteriori knowledge that the sun is what has caused the wax to melt (A766/B795).

In the continuation of the above passage, Kant then proceeds to criticize Hume for failing to appreciate this distinction and, as a result, for inferring the contingency of particular causal laws from the contingency of our knowledge of them:

He [Hume] therefore falsely inferred from the contingency of our determination in accordance with a law the contingency of the law itself, and he confused going beyond the concept of a thing to possible experience (which takes places a priori and constitutes the objective validity of the concept) with the synthesis of the objects of experience, which is of course always empirical; thereby, however, he made a principle of affinity, which has its seat in the understanding and asserts necessary connection, into a rule of association, which is found merely in the imitative imagination and which can present only contingent combinations, not objective ones at all. (A766-7/B794-5)

Although our knowledge that the sun (as opposed to some other cause) melts the wax relies essentially on experience, then, Kant insists that the causal law itself has an a priori ground and is thus necessary. And it is because Hume does not recognize this distinction, Kant suggests, that he fails to realize it is a mistake to infer anything about the modality of a causal laws from the 
empirical conditions of their discovery. Moreover, Kant proceeds to describe this mistake as a confusion of the empirical synthesis of the reproductive or, as Kant here describes it, the imitative (nachbildenden) imagination with the transcendental synthesis of the productive imagination. ${ }^{23}$ Put in a more general way, Kant's central claim in this passage is that Hume's denial of genuinely necessary causal relations and his related denial of all synthetic a priori cognition are both results of his failure to acknowledge that there is a fundamental difference between our experience of the world (including our experience of ourselves) and the transcendental operations of the mind that Kant believes make this experience possible.

Now, it is difficult to say more about either of these passages without going into the details of the account of cognition Kant develops in the Transcendental Aesthetic and Transcendental Analytic. But such an excursion is not necessary for our purposes. In particular, since it is clear that Kant has framed his criticisms of Hume in terms of this account, the relevant question is whether Kant is simply diagnosing Hume's mistakes from the perspective of his positive view or offering this view as a reason to reject Hume's account of causation. Given the context of the passages, I think it is clear that Kant is doing the latter. If we return to the beginning of the second passage, we see that Kant presents his analysis of Hume's mistakes as one that follows from the views of the Second Analogy that are sketched in the first passage. For it is precisely these views that Kant appeals to in order to justify the claim that Hume mistakenly inferred "the contingency of the law itself" from "the contingency our determination in accordance with a law" (A766/B794) ${ }^{24}$ In other words, Kant presents his own account of causation not merely as an alternative to Hume's account but as a reason to reject this account as false. And this is a move that only makes sense if we suppose that, pace Watkins, Kant did conceive of his account as a refutation of Hume's.

Thus, while Watkins is right to insist that Kant thought of Hume's account of causation as a forerunner to his own critique of metaphysics, he is wrong to insist that this was the only feature of Hume's account Kant believed was relevant to his aims in the Critique. Rather, as the passages from the Critique and Prolegomena show, Kant also believed that Hume's account commits him to the denial of synthetic a priori cognition. By itself, this view about the implications of Hume's account of causation gives us reason to read Kant's attempt to explain

\footnotetext{
${ }^{23}$ For discussion of this distinction, see B151-2.

${ }^{24}$ This is the force of the "therefore" at the beginning of the second passage.
} 
the possibility of synthetic a priori cognition in the Aesthetic and Analytic as an attempt to refute Hume. But Kant's comments in the Discipline have also shown us that he believes the arguments of the Second Analogy play an important role in this refutation. And these comments, which remain unchanged in the second edition, are a first-hand account of what Kant thought he was doing in the Critique.

\section{HUME’S EARLY GERMAN CRITICS}

Consider finally the third prong of Watkins' argument: his claims about the effect the early German response to Hume likely had on Kant. Hume's views on causation were discussed by three German philosophers prior to the publication of the Critique: J. G. Sulzer, Moses Mendelssohn, and J. N. Tetens. ${ }^{25}$ Sulzer's 1755 German edition of Hume's Enquiry contains an extensive commentary on Hume's views on causation. Mendelssohn's 1756 essay "Thoughts on Probability" extends and formalizes Sulzer's critique. And Tetens' 1777 Philosophical Essays on Human Nature and its Development contains a more sympathetic discussion and critique of Hume's views. ${ }^{26}$ Moreover, there is ample evidence that Kant read each of these texts prior writing the Critique, making each an important part of the context in which he thought about the relevance of Hume's views on causation to his own project in the Critique. ${ }^{27}$

But while Hume's views on causation attracted interest among Kant's contemporaries, they did not attract adherents. And it is this tepid reception that initially gives Watkins's conclusion an air of plausibility. It was the style of Hume's Enquiry more than its content that

\footnotetext{
${ }^{25}$ Watkins discusses Sulzer and Tetens in some detail but mentions Mendelssohn only in passing. Sulzer was a member of the Berlin Royal Academy of the Sciences from 1750 until his death in 1779, during which time he published a number of philosophical works on various topics culminating in his two-volume General Theory of the Fine Arts in 1771 and 1774. Both he and Mendelssohn were among the three philosophers in Berlin to whom Kant sent a copy of his Inaugural Dissertation. Mendelssohn is perhaps best remembered for having written the essay that was chosen over Kant's in Berlin Academy's 1763 prize essay competition but was active in virtually every aspect of eighteenth-century German intellectual life. Finally, Tetens served variously as a professor of physics, philosophy, and mathematics first at Bützow then at Kiel before accepting a position in the Danish court in 1789. Although Mendelssohn is the only one likely to be remembered today, each was thus held in high esteem during his lifetime.

${ }^{26}$ Tetens also discusses Hume in his 1776 essay "Über die allgemeine spekulative Philosophie". But since his treatment of Hume there is virtually identical with the otherwise more detailed treatment of the Philosophical Essays, I will not discuss the earlier work here.

${ }^{27}$ Kant makes explicit reference to Sulzer's edition of the Enquiry in a logic transcript from the early 1770's and had likely read it long before then. In a letter from the same period, Mendelssohn offers to send Kant a copy of his Philosophical Writings, which includes "Thoughts on Probability". And Kant discusses Tetens in two reflections from the late 1770's and comments explicitly on the Philosophical Essays in a letter to Herz from April, 1778. See 24:218, 10:113-16, 18:23 and 10:230-2.
} 
motivated Sulzer to publish it and recommend it to his German contemporaries. ${ }^{28}$ And both he and Mendelssohn believe that Hume's arguments, particularly those concerning causation, turned on fairly obvious mistakes. Finally, despite being more sympathetic to Hume's empiricism, Tetens rejects his account of the content of our idea of necessary connection and consequently most of his account of causation. Since none of Kant's contemporaries found Hume's views on causation compelling and many offered their own explicit critiques of them, Watkins concludes that by 1781 "neither Kant nor his readers would have thought that Hume's position stood in need of refutation in the first place". ${ }^{29}$

Upon reflection, however, this argument is stunningly weak. First, it appears to assume that Kant exercised little independence in deciding what is philosophically relevant. ${ }^{30}$ His contemporaries may have thought that Hume's views were simple-minded or obviously mistaken. But there is no reason to assume that Kant would have agreed with them about this when he disagreed with them about so many other things such as the possibility of cognizing supersensible objects like God and the soul. More importantly, in order to make Kant think that an additional critique of Hume would be otiose, these early criticisms would have to be successful by standards that Kant would accept. And it is easy to show that Kant would have good reason to reject all of them. ${ }^{31}$ As I will argue in the remainder of this section, Sulzer and Mendelssohn both beg the question against Hume, while Tetens ignores the central part of Hume's view only to offer an alternative account of causation that is just as unacceptable to Kant as Hume's is.

Manfred Kuehn has commented that Sulzer's refutation of Hume "is remarkable only for the persistence with which it misses the point". ${ }^{32}$ And a brief look at one of Sulzer's arguments will show us why. In the Enquiry, Hume denies that our expectation that bread will nourish us in the future as it has nourished us in the past is the result of a chain of reasoning and challenges anyone unsatisfied with this denial to produce the reasoning by which this expectation arises. ${ }^{33}$

\footnotetext{
${ }^{28}$ See Hume 1755, a4. For discussion, see Kuehn 1983, 178-180, Kreimendahl and Gawlick 1987, 20-22, and Watkins 2005, 364-5.

${ }^{29}$ Watkins 2005, 372.

${ }^{30}$ ACKNOWLEDGMENT

${ }^{31}$ Unfortunately, there is no record of Kant's responses to these early critiques. So anything said about his reaction to them must be somewhat speculative. But as we will see, the inadequacies of Sulzer's and Mendelssohn's responses are glaring, and Kant's dissatisfaction with Tetens' positive account is documented by comments in his unpublished work.

${ }^{32}$ Kuehn 1983, 181 note 21.

${ }^{33}$ See Enquiry 4.16; SBN 32-4.
} 
Sulzer is eager to accept this challenge. But he is also perplexed that Hume was unable to produce the chain of reasoning himself. For "it is obvious," according to Sulzer:

that in the current case the mind acts according to the most precise rules of reason. It builds all of its expectation on one proposition, [namely] that the same causes must have the same effects, a proposition that always remains true in the strongest sense [...] (Hume $1755,99)$

In light of this principle, Sulzer believes that one should be able to reason in the following way:

What I see before me has all of the sensible properties of bread. I have always experienced that bread gives healthy nourishment, [and] therefore this [bread] must also have that property. (Hume 1755, 99)

Thus, Sulzer's response to Hume's denial that our expectations about the future are based on a chain of reasoning is to assert a version of the very proposition whose justification is at issue, namely that the future will resemble the past. And Sulzer's other arguments, although too numerous to discuss here, are just as question-begging.

Mendelssohn's response is more detailed than Sulzer's, but it is ultimately just as ineffective. As Mendelssohn understands it, Hume has attacked the justification of "all our judgments that are founded on experience, analogy, or induction". ${ }^{34}$ He believes that Sulzer has responded to this attack "thoroughly enough" and frames his own response as an elaboration of Sulzer's that attempts to use the "principles of probability to make [our] inferences from analogy, experience, etc. more clear". Thus, Mendelssohn's goal is to use principles of probability to give a more precise characterization of the inferences whose rational justification he believes Sulzer has already established.

How does Mendelssohn think that probability will help us articulate what is rational about our inferences concerning cause and effect? When two events occur simultaneously or in close temporal succession, he believes there are three possibilities regarding their potential causal relationship:

[E]ither the event $\mathrm{A}$ is grounded in the event $\mathrm{B}$, or $\mathrm{A}$ and $\mathrm{B}$ are subordinate to a third (near or distant) cause $\mathrm{C}$, or finally $\mathrm{A}$ and $\mathrm{B}$ are effects of entirely different causes, whose existences in no way depend on another. (Mendelssohn 1971 [1756], 158)

\footnotetext{
${ }^{34}$ Mendelssohn 1971 [1756], 156. Like Sulzer's, Mendelssohn's critique of Hume is based on his views in the first Enquiry.
} 
In the first case, the two events stand in a direct causal relationship, and we can give a reason for their occurrence. And in the second, they stand in an indirect causal relationship in virtue of being grounded in a common cause. But in the third case, Mendelssohn says:

[I]t is not at all grounded in the essential qualities of A and B that they should come together at the same time and it is to be looked at as a mere coincidence [Zufall] that both causes, which the events A and B bring forth, are throw together at the same time. (Mendelssohn 1971 [1756], 158)

We can already appreciate why Kant would have regarded Mendelssohn's approach as unsatisfactory. For by assuming that we can know an object's essential nature, Mendelssohn helps himself to one of the claims Hume means to deny when he claims that our knowledge of casual relations is not "founded on reason" (E 4.15; SBN 32). ${ }^{35}$ If we grant the metaphysical picture implicit in these quotes, however, we can see that what Mendelssohn would need to do to show that our inferences concerning cause and effect are rational is to show that we have principled reasons for excluding this third possibility in particular cases. That is, if we can show that the occurrence of two things is not coincidental, we have reason to believe that there is a causal relationship between them.

This is where the appeal to probability comes in. Mendelssohn argues that the more frequently we observe the simultaneity or succession of two events, the less likely it becomes that their occurrence is coincidental and the more likely it becomes that there is a causal connection between them. ${ }^{36}$ In particular, the probability that $\mathrm{A}$ and $\mathrm{B}$ have no causal relation to each other after $n$ observations is $1 / \mathrm{n}+1$ and thus can be shown to be arbitrarily close to zero given a sufficient number of observations. Thus, it is through repeated observation that we gain highly probable knowledge about the causal properties of objects and thus are able to make highly probable inferences about the future. And since these inferences are based on mathematical principles, they are rational. ${ }^{37}$

\footnotetext{
${ }^{35}$ For a reading of Hume's argument in Section IV of the Enquiry along these lines, see Buckle 2001, 149-68.

${ }^{36}$ As Mendelssohn puts it, "the supposed third case, namely that the two events are not in any way grounded in another, becomes less probable the more often one sees the same events occurring at the same time". (Mendelssohn $1971[1756], 158)$

${ }^{37}$ In the case of bread, for example: "The sensible properties of bread are either immediately connected with its powers of nourishment or they are both grounded in the inner essence of the bread, like in a mutual cause, or, finally, it was a mere coincidence that these external constitutions have meet with these powers of nourishment. The probability of the last case is related to certainty as 1 is to $n+1$; thus, the probability of the contrary case [is related] to certainty as $n$ to $n+1$. The more often this experience is had, the nearer our expectation comes to certainty, and if $n$ were infinite we would be completely certain" (Mendelssohn 1971 [1756], 160)
} 
I have already observed that Mendelssohn is not entitled to the metaphysical assumptions underlying his argument. But it is important to see that ignoring this metaphysical picture does not save his response. For the only reason we would think that repeated observations would make a belief in the causal connection between two events more probable is if we at least tacitly supposed that the future will resemble the past. Otherwise, there is no reason to be more certain that the thousandth piece of bread will nourish us than that the first will. But again, the proposition that the future will resemble the past is precisely the principle for which Hume says we have no rational justification. Like Sulzer's, Mendelssohn's “refutation" of Hume simply begs the question against him. ${ }^{38}$

Tetens' response to Hume is not question-begging, at least not obviously so. But his critique would have been unacceptable to Kant for different reasons. Tetens' fundamental disagreement with Hume is that his account of causation fails to capture the idea that the relation of cause and effect is a necessary one. After briefly summarizing Hume's account, he asks rhetorically if the "representation of the constant succession" of one object after another "exhausts our entire concept of the causation of the one through the other". ${ }^{39} \mathrm{He}$ then proceeds to answer his own question:

We rather represent it in the following way: that the effect is dependent on the cause, is brought about by it, and made actual through it. Does not this latter representation contain other additional ideas [Nebenideen] besides constant succession? We look at the effect as something that is intelligible [begreiflich] through its cause! (Tetens 1777, 316)

For Tetens a cause is something that, when properly understood, explains its effect and makes it intelligible. And he criticizes Hume for thinking that this intelligibility is "merely a consequence of a previous association of ideas". 40

Of course, Hume does not deny that our concept of cause or our beliefs about causal relations include the idea of necessary connection. Indeed, he goes to great pains to show us that the origin of this idea is an internal impression that arises as a natural consequence of the mind's perceiving two or more objects in constant conjunction. ${ }^{41}$ So it is quite misleading for Tetens to suggest that Hume believes our "entire concept of causation" is exhausted by the "representation of the constant succession" of two objects and "merely a consequence of a previous association

\footnotetext{
${ }^{38}$ For a discussion of the context in which Mendelssohn wrote his essay, see Altman 1973, 74-83 and Kuehn 1995.

${ }^{39}$ Tetens 1777,316

40 Ibid.

${ }^{41}$ See Enquiry 7.26-30; SBN 73-79 and Treatise 1.3.14; SBN 155-179.
} 
of ideas". ${ }^{42}$ But Tetens has a bigger problem than his faulty understanding of Hume's positive view. For it is not at all clear how the understanding can make the judgments about causal relations Tetens believes it does without relying on general principles about the behavior of objects that for Hume are not strictly necessary.

Causal connection for Tetens is a necessary relation that obtains in virtue of certain relations among concepts. But while this relation is intellectual, Tetens does not think it is analytic like relations of ideas are for Hume and thus does not believe that it is a relation that could be discovered to hold among objects a priori. Rather, he thinks that we come to believe that two objects stand in causal relation through an act of reasoning, which, though it is not an $a$ priori act, still carries with it a kind of necessity. ${ }^{43}$ Tetens illustrates this act and the kind of necessity associated with it by using the familiar example of the impact of two billiard balls:

One ball takes its path towards the other, and two objects cannot take up the same place simultaneously. This would have to take place, if the striking ball followed its path unhindered and the resting [ball] should remain in its place unchanged. (Tetens 1777, 319)

Thus, so goes Tetens implicit conclusion, we reason that the first ball must push the other away. He continues:

[...] it is undeniable that we undertake the said reasoning and that we afterwards consider ourselves convinced that our judgment of the efficient connection between the impact and its effect is also in general a true judgment more because of this reasoning than by sensation. (Tetens 1777,319 )

Although it begins with the senses, then, it is thus the judgment of reason that completes our knowledge of causal connections.

What would Hume make of this example? He might regard it as necessary that "two objects cannot take up the same place simultaneously" since this proposition might be regarded as a relation of ideas. But he would certainly deny that it was necessary for the one ball to push the other away. For it implies no contradiction, we might suppose Hume to say, that the impact of two billiard balls annihilate the one ball, fuses it with the other, or transports them both to

\footnotetext{
${ }^{42}$ Tetens 1777,316

${ }^{43}$ The thought that Tetens is reaching for but failing to grasp is that our cognition of causal relations is somehow $a$ priori and synthetic. It is not merely logical since there are no containment relationships among the relevant concepts, but it is not wholly empirical either since the judgments are necessary. Thus, Tetens's response to Hume illustrates the need for an answer to the question of the possibility of synthetic a priori knowledge that governs the structure of the Critique. Tetens does not appreciate the need to establish the possibility of such knowledge. Otherwise, Kant might have listed him with Locke and Hume in the Prolegomena as one of the philosophers who anticipated the need to give an account of how synthetic a priori cognition is possible.
} 
some other location. More importantly, the only reasons Tetens could give us to explain why his inference is better than any of these alternatives are ones that rely on generalizations about the behavior of balls or other physical objects. And for Hume these generalizations never hold necessarily. So it appears that Tetens simply rejects Hume's view that claims about causal relations are never strictly necessary in favor of his own account without offering any independent considerations against it. And while this rejection is not quite question-begging, it is a failure to address one of the most important aspects of Hume's account.

In a latter section of the Philosophical Essays, it becomes clear that Tetens does not address this aspect of Hume's account because he does not consider it a problem for his own. In particular, Tetens believes it is possible to deduce objectively necessary principles and judgments about the world by identifying judgments that are, in his words, "subjective necessary", that is, judgments that observation of the workings of our own minds tells us that we always make. As he puts it:

We cognize the subjective necessity to think according to the universal laws of the understanding through observation. We sense that we cannot represent a square circle and can consider no thing distinct from itself. We ground the objective on this subjective necessity: we transfer the impossibility of thinking of the things differently to the things outside of the understanding. Our ideas are now no longer ideas in us; they are things outside us. (Tetens 1777, 531)

According to Tetens, then, there is no difference between the objectively necessary and what he calls the "unchangeable and necessary in the subject". ${ }^{44}$ To say that something is necessary and objective is simply to say that we cannot think it otherwise, and what we cannot think otherwise reveals itself through observation of our own minds. ${ }^{45}$

More could be said about Tetens' critique of Hume and his own Hume-inspired position. But what is important for our purposes is that both are unacceptable to Kant. Kant rejects the identification of subjective necessity with objectivity that Tetens believes marks the decisive advance of his account over Hume's and, indeed, makes it the goal of the Transcendental Deduction to show "how the subjective conditions of thinking should have objective validity" (A89-90/B122). More importantly, in the Kantian idiom, the alternative account of causation that Tetens has offered us amounts to an empirical not a transcendental deduction of the concept of cause-that is, an attempt to show how the concept "is acquired through experience and

\footnotetext{
${ }^{44}$ Tetens $1777,561$.

${ }^{45}$ See Beck 1969, 421-5 for a more detailed discussion of Tetens' account of objectivity.
} 
reflection" not an attempt to establish that we not only possess the concept but that our use of it is lawful (A84/B116 and A87/B119). And Kant is quite clear that empirical deductions of concepts like cause cannot explain how we can have knowledge of causal relations. They are, he says, "nothing but idle attempts, which can occupy only those who have not grasped the entirely distinctive nature of these cognitions" (A87/B119).

Indeed, we need not even speculate about whether Kant thought that Tetens' account of causation amounted only to an empirical deduction of the concept. For in two reflections written sometime between 1776 and 1778, Kant contrasts his approach to the investigation of concepts with Tetens' in a way that reflects the distinction he later makes between empirical and transcendental deductions:

I concern myself not with the evolution of concepts, like Tetens (all actions by means of which concepts are produced), nor with their analysis, like Lambert, but solely with their objective validity. I am not in competition with these men. (R 4901, 18:23)

Tetens investigates the concepts of pure reason merely subjectively (human nature), I investigate them objectively. The former analysis is empirical, the latter transcendental. (R 4900, 18:23) $)^{46}$

By Kant's own admission, then, Tetens' account of cognition in general and his response to Hume in particular are blind to the distinction that Kant insists is essential to determining whether synthetic a priori cognition is possible. ${ }^{47}$ And since one of Kant's chief criticisms of Hume is that his account of causation forces him to deny this possibility, Tetens' response can only have struck Kant as inadequate.

\section{CONCLUSION}

Watkins holds that Kant's account of causation relies on a model of causation that is fundamentally different from the one implicit in Hume's account in the Treatise. In this paper, I have not considered whether this claim is correct. But I have argued that determining whether it

\footnotetext{
${ }^{46}$ Kant 2005, 199.

${ }^{47}$ See, for example, 4:260. Kuehn concurs with this assessment and even suggests that Kant's development of the distinction between empirical and transcendental deductions may have been due to his reading Tetens. See Kuehn 1989, 373f. The textual work needed to substantiate this claim goes beyond the scope of the present essay, but it is worth noting that there is additional evidence of Kant's interest in Tetens in the late 1770's. On October 13, 1777, Hamann wrote to Herder that Kant was "said to be very full of [...] Tetens" (Hamann 1955-9 vol. 3, 376f.). And by Hamann's account, this was still the case two years later. For in his letter to Herder of May 17, 1779, he writes that Kant is working on the Critique and that he "always has Tetens before him" (Hamann 1955-9 vol. 4, 80-2). See also Kant's October 15, 1789 letter to Hartknoch.
} 
is not relevant to evaluating the further claim that the arguments of the Analogies of Experience are not an attempt to refute Hume. Kant's knowledge of Hume was based primarily on the Enquiry, which does not include the arguments for the finite divisibility of time crucial to Hume's conception of events in the Treatise. Moreover, these arguments are fallacious. So even if Kant did have access to them, there is no reason to expect him to provide independent arguments against them. And whatever the details of Kant's arguments in the Analogies, we must bear in mind that his account of causation is their conclusion not one of their premises. So even if we are to insist that Kant needs a way to undermine the event-event model of causation implicit in the Treatise, he can still do so in the way he is typically thought to, namely by showing that Hume's tacit reliance on our knowledge of objective succession can only be justified on the assumption that the principles of the Analogies are true.

I have also argued that Kant's comments about Hume in the Prolegomena and especially in the Discipline of the Critique show that Kant conceived of his account of causation as a refutation of Hume. In addition to crediting Hume for having aims similar to his own and, in particular, with wanting to curb the claims of speculative reason, Kant also criticizes Hume for attempting to do so in a way that is both unsuccessful and incompatible with any genuinely necessary knowledge of causal relations or of any of the other things about which Kant believes we have synthetic a priori knowledge. And when he makes these criticisms in the Discipline, he also presents his own account of causation not merely as an alternative to Hume's but as a reason to reject it.

Finally, while Kant's contemporaries may have thought they refuted Hume's account of causation, I have argued that Kant would not have agreed with them. Sulzer and Mendelssohn beg the question against Hume by either assuming the validity of the principle that the future will resemble the past or appealing without argument to our knowledge of essential natures. Tetens rejects central aspects of Hume's account. But his arguments against Hume are not conclusive, and his alternative account of causal judgment is nearly as objectionable to Kant as Hume's account. With clear interest in Hume among Kant's contemporaries but no effective critique, 
there is no reason to think that Kant would have regarded an additional critique of Hume as otiose. On the contrary, the middling responses by Sulzer, Mendelssohn, and Tetens may well have emphasized to Kant the need for a more comprehensive critique. Whether they did is, unfortunately, a matter of speculation. But it should now be clear that the translator of Reid's Inquiry was right to identify Kant as one of Hume's critics and that refuting Hume's account of causation is indeed a central aim of the Analogies of Experience and, more generally, of the Critique.

\section{BIBLIOGRAPHY}

Allias, L. 2007. Review of Kant and the Metaphysics of Causality. British Journal for the History of Philosophy 15 (1): 213-218.

Allison, H. 2008. Custom and Reason in Hume: A Kantian Reading of the First Book of the Treatise. Oxford: Oxford University Press.

Beck, L. W. 1969. Early German Philosophy: Kant and His Predecessors. Cambridge: Belknap.

Buckle, S. 2001. Hume's Enlightenment Tract: The Unity and Purpose of An Enquiry Concerning Human Understanding. New York: Oxford University Press.

Erdmann, B. 1888. “Kant und Hume um 1762.” Archiv für Geschichte der Philosophie 1: 62-77, 216-230.

Fischer, K. 1860. Immanuel Kant: Entwicklungsgeschichte und System der kritischen Philosophie. Manmhein: Friedrich Zasserman.

Flew, A. 1976. "Infinite Divisibility in Hume's Treatise". In Hume: A Re-evaluation. Ed. D.W. Livingston and J.T. King. New York: Fordham University Press, 257-69.

Fogelin, R. 1988. "Hume and Berkeley on the Proofs of Infinite Divisibility" The Philosophical Review 97: 47-69

Frasca-Spada, M. 1990. "Some Features of Hume's Conception of Space" Studies in History and Philosophy of Science 21: 371-411.

Gawlick, G. and Kreimendahl, L. 1987. Hume in der deutschen Aufklärung: Umrisse einer Rezeptionsgeschichte. Stuttgart-Bad Cannstatt: Frommann-Holzboog.

Giovanni, G. and Harris, H.S. (ed.) 2000. Between Kant and Hegel. Indianapolis: Hackett. 
Guyer, P. 2008. Knowledge, Reason, and Taste: Kant's Response to Hume. Princeton and Oxford: Princeton University Press.

Hamann, J.G. 1955-59. Johann Georg Hamann Briefwechsel. 6 volumes. Ed. A. Henkel and W. Ziesemer. Wiesbaden: Insel Verlag.

Hatfield, G. 2001. "The Prolegomena and the Critiques of Pure Reason". In Kant und die Berliner Aufklärung. Ed. R. P. Horstmann V. Gerhardt, and R. Schumacher. Berlin: de Gruyter, 185-208.

—. 2003. "What Were Kant's Aims in the Deduction?" Philosophical Topics 31: 165-198.

Holden, T. 2002. "Infinite Divisibility and Actual Parts in Hume's Treatise" Hume Studies 28 (1): 3-26.

Hume, D. 1755. Philosophische Versuche über die menschliche Erkenntnis. Hamburg and Leipzig: Georg Christian Grund und Adam Heinrich Holle.

1978 [1739-40]. A Treatise of Human Nature. Ed. P.H. Nidditch with an analytical index by L.A. Selby-Bigge. Oxford: Oxford University Press.

2000 [1748]. An Enquiry Concerning Human Understanding. Ed. Tom L. Beauchamp. New York: Oxford University Press.

Kant, I. 1900-. Kants gesammelte Schriften. Ed. Königliche Preußische Akademie der Wissenschaften. Berlin.

1998 [1781/7]. The Critique of Pure Reason. Transl. P. Guyer and A. Wood. Cambridge and New York: Cambridge University Press.

- 2004 [1783]. Prolegomena to any future metaphysics that will be able to come forward as science. Transl. G. Hatfield. Cambridge and New York: Cambridge University Press.

- 2005. Notes and Fragments. Transl. and ed. C. Bowman, P. Guyer, and F. Rauscher. Cambridge and New York. Cambridge University Press.

Kemp-Smith, N. 1918. A Commentary to Kant's Critique of Pure Reason. London: Macmillian.

Kuehn, M. 1983. "Kant's Conception of Hume's Problem.” Journal of the History of Philosophy 21:175193.

- 1987b. "Kant's Transcendental Deduction: A Limited Defense of Hume." In New Essays on Kant. Ed. B. Ouden and M. Moen. New York: Peter Lang.

—. 1989. "Hume and Tetens". Hume Studies. 15(2): 365-376.

—. 1995. "David Hume and Moses Mendelssohn". Hume Studies. 21(2): 197-220.

Mendelssohn, M. 1971 [1756]. “Gedanken von der Wahrscheinlichkeit”. In Gesammelte Schriften: Jubiläumsausgabe. volume 1. Ed. F. Bamberger. Stuttgart-Bad Cannstatt, Frommann-Holzboog, 149-164. 
- 1971 [1771]. Philosophische Schriften. In Gesammelte Schriften: Jubiläumsausgabe. volume 1. Ed. F. Bamberger. Stuttgart-Bad Cannstatt: Frommann-Holzboog, 229-515.

Pistorius, H. A. 1786. Review of Schultz's Erläuterung über des Herrn Professor Kant[s] Critik der reinen Vernunft. In Allgemeine Deutsche Bibliothek. May, 92-123.

Read, R. and Richman, K. (ed.) 2008. The New Hume Debate: Revised Edition. New York: Routledge.

Reid, T. 1782. Untersuchungen über den menschlichen Geist, nach den Grundsätzen des gemeinen menschen Verstandes. Leibzig: Schwickert.

Reinhold, K. L. 1791. Über das Fundament des philosophischen Wissens. Jena: Johnn Michael Mauke.

Sassen, B. (ed.) 2000. Kant's Early Critics: The Empiricist Critique of the Theoretical Philosophy. Cambridge and New York: Cambridge University Press.

Schultz, J. 1785. Review of J.A.H. Ulrich's Institutiones logicae et metaphysicae. In Allgemeine Literatur Zeitung. December 13, 297-299.

Schulze, G. E. 1792. Aenesidemus, oder über die Fundemente der von dem Herrn Prof. Reinhold in Jena gelieferten Elementarphilosophie, nebst einer Verteidigung gegen die Anmassungen der Vernunftkritik.

Tetens, J. N. 1776. "Über die allgemeine spekulative Philosophie". Bützow and Wismar: Berger und Boednershen Buchhandlung.

- 1777. Philosophische Versuche über die menschliche Natur und ihre Entwickelung. Leipzig: M.G. Weidmanns Erben and Reich.

Tiedemann, D. 1785. "Über die Natur der Metaphysik; zur Prüfung von Hrn Professor Kants Grundsätze". In Hessische Beiträge zur Gelehrsamkeit und Kunst 1, 113-30.

Vaihinger, H. 1881. Commentar zu Kants Kritik der reinen Vernunft, vol. 1. Stuttgart: Spemann.

Watkins, E. 2004. "Kant's Model of Causality: Causal Powers, Laws, and Kant's Reply to Hume." Journal of the History of Philosophy 42(4): 449-488.

2005. Kant and the Metaphysics of Causality. Cambridge and New York: Cambridge University Press. 